\title{
Vaikuttava oppiminen on sidoksissa oppijan oppimis- ja kehitysprosesseihin
}

Esa Poikela

\author{
Kontekstuaalinen oppiminen on raportin teoriavaiheen \\ tulema, jonka tarkoituksena on osoittaa, että työssä \\ oppiminen, työyhteisössä oppiminen ja koko \\ organisaation oppiminen on luonteeltaan \\ kontekstuaalista. Oppiminen ja kehittyminen on \\ murtautumista kontekstista toiseen, aina syvempään ja \\ laajempaan työn ja toiminnan kontekstiin.
}

$\Upsilon_{\text {pim }}$ utkimus 'Kontekstuaalinen oppiminen - oppimisen organisoituminen ja vaikuttava koulutus' käsittelee oppimisen organisoitumista ja koulutuksen vaikuttavuutta yhden täydennyskoulutusorganisaation puitteissa. Tavoitteena on tavanomaista syvemmän tutkimusotteen ja näkökulman saavuttaminen, mihin ei yleensä laajoilla lomakekyselyillä yletytä. Sana ORGANISOITUMINEN korostaa oppimisen riippuvan enemmän yksilöistä ja heidän elämänyhteisöistään kuin koulutuksen organisoimisesta. Ts. oppiminen mahdollistaa koulutuksen. Tällöin koulutus ei ole syy oppimiseen, vaan pikemminkin päinvastoin. Koulutuksen ja oppimisen tulosten välillä oletetaan kuitenkin vallitsevan kausaalisuhteen: koulutuksella oletetaan olevan vaikuttavuutta niin yksilöiden kuin organisaatioidenkin käyttäytymiseen.

$\mathrm{T}$ utkimuksen keskeisiä teemoja ovat työssä oppiminen, asiantuntijuuden kehittyminen ja organisationaalisen osaamisen tuottaminen sekä koulutuksen vaikuttavuus. Teemoja ei ole kuitenkaan käsitelty minkään ennalta laaditun teoriakehyksen tai hypoteesien puitteissa. Niin organisoitumisen kuin vaikuttavuudenkin ongelmaa on haluttu lähestyä oppimisen ja tutkittavien itsensä näkökulmasta.

Valittu metodologinen lähestymistapa noudattaakin aineistolähtöisen grounded-teorian yleisiä periaatteita. Analyysivälineenä käytetään tutkimushaastatteluista laadittuja KÄSITEKARTTOJA, joille haetaan tieto-opillinen perustelu kognitiivisten karttojen evoluutioteoriasta.

Tutkimuksen ensimmäinen osa on tausta-anaLyysi, jossa tehtãvănă on kirjoittaa auki erãănlainen metateoria, sillä aineistolähtöinenkään tutkimus ei ala tyhjästä. Toinen osa on empiirinen analyysi, jossa kuvataan koulutusohjelmaan osallistuneiden ja koulutusta suunnittelevien henkilöiden toimintaa ja ajattelua heidän itsensä kuvaamalla tavalla. Haastatteluista laadittujen kä- 
sitekarttojen ja niiden poikittais- ja pitkittäisvertailun tavoitteena on saada mahdollisimman syvällinen kuva yksilöiden sekä työyhteisön ja organisaation toiminnasta ja kehityksestä.

$\mathrm{K}$ olmas osa on teoria-analyysi, jossa empiirien analyysin tulokset ja johtopäätökset on aluksi koottu kohdetta kuvailevan ja selittävän erityisteorian eli substantiivisen teorian muotoon. Tämän jälkeen tulokset on johdettu teoreettisen yleistyksen eli formaalisen teorian tasolle, joka puolestaan on asetettu kriittiseen diskurssiin muiden vastaavia ilmiöitä selittävien teorioiden kanssa.

$\mathrm{T}$ utkimuksen nimi 'kontekstuaalinen oppiminen’ kertoo pähkinän kuoressa, mistä työssä oppimisessa, asiantuntijuuden ja organisaation ydinosaamisen tuottamisessa on perustaltaan kysymys. Yksilöt oppivat työssään murtautuen yksilöllisestä työstään syvemmälle ja laajemmalle yhteisen työn kontekstin kautta koko organisaation työn ja aina käsitteellisen työn kontekstiin saakka. Ammatillinen ja organisationaalinen kehitys kietoutuvat toisiinsa tavalla, joka tekee osaamisesta entistä organisaatiospesifimpää, mutta myös entistä laaja-alaisempaa työelämän yleisten pätevyyksien suhteen. Vaikuttava koulutus on koulutussuunnittelijoiden korkeatasoisen osaamisen tulosta, joka puolestaan on organisationaalisen oppimisen ja tiedonmuodostuksen prosessien ohjaamisen ja kehittämisen tulosta. Näitä prosesseja kuvataan tutkimuksessa palaute-, arviointi- ja evaluointitiedon kautta oppimiseksi.

$\mathrm{P}$ alaute- ja arviointitiedon tuottaminen liittyy organisaation sisäisiin toimintaprosesseihin ja -konteksteihin. Evaluointitiedon hankkiminen on sidoksissa organisaation ulkoisiin prosesseihin ja erilaisiin verkostoyhteyksiin, joissa toimitaan monimutkaisten valta- ja vaikutussuhteiden kontekstissa. Toimintakontekstit määrittävät oppimisen ehtoja ja suunnan samalla, kun hankittu kokemus vahvistaa opitun merkityksen ja laadun.

Y dinosaamisen tuottamisen peruskysymys on, miten professionaalinen kehitys, oppimisen ja tiedontuottamisen prosessit kyetään organi- saatiossa sovittamaan yhteen. Lisäksi täytyy kysyä, mistä ja miten elintärkeä tieto saadaan, hankitaan ja tuotetaan organisaation sovittaessa itseään ulkoisen kilpailun ja valtasuhteiden kenttään. Kyse ei ole vain organisaation sisäisistä oppimisen ja tiedon tuottamisen prosesseista, joista tutkittua tietoa on jo suhteellisen runsaasti. Tässä tutkimuksessa nostetaan esiin myös organisaatioiden ja instituutioiden välisien toiminta- ja vaikutusprosessien tutkiminen yksilöllisen oppimisen ja kehittymisen sekä organisationaalisen osaamisen lähteenä. Vaikuttavan koulutuksen metafora on neuvottelu ja holografia, jotka kertovat kouluttavan ja koulutettavan osapuolen välisestä keskinäisestä riippuvuudesta. Kouluttava organisaatio kykenee parhaiten tuottamaan koulutusta, jonka merkitykset ja sisällöt se on käynyt omassa toiminnassaan läpi. On siis eroteltavissa toisaalta yleinen ja yhteinen maailma, jota kuvaavat holografiset prosessit ovat läpinäkyviä ja samankaltaisia eri organisaatioissa. Toisaalta on olemassa erityinen ja erilaisuuksien maailma, jossa käsiteltävistä asioista on neuvoteltava erikseen asiakkaiden ja muiden vaikuttajien kanssa.

ika, paikka ja tilanne ratkaisevat koulutuk-
lsen laadun ja tehokkuuden. Vaikuttavan koulutuksen tärkein ehto on sen oikea ajoittaminen, ts. sovittaminen asiakkaan oppimis- ja kehitysprosesseihin. Oppimisen tuloksellisuuden ratkaisee yhteinen foorumi, jolla oppijat ja ohjaajat käsittelevät, syntetisoivat ja arvioivat yksin ja yhdessä hankkimaansa tietoa, jonka lähteet voivat olla yhtälailla yksilöiden kokemuksissa kuin yleisissä teorioissakin.

Väitöskirjatutkimukseni avainsanoja ovat kontekstuaalinen oppiminen, työssä oppiminen, ammatillinen kehittyminen, asiantuntijuus, koulutussuunnittelu, pedagoginen johtaminen, oppiva organisaatio ja ydinosaaminen.

Tiivistelmä Lectio praecursorianista

Esa Poikelan väitöskirjatutkimus

'Kontekstuaalinen oppiminen - oppimisen organisoituminen ja vaikuttava koulutus' tarkastettiin Tampereen yliopistossa 29.5.1999. 